\title{
Efektivitas Etika Digital Netizen Indonesia Terhadap Ujaran Kebencian di Instagram
} Azizah Pauleta Arthamevia ${ }^{1}$,Rachel Arifa ${ }^{2}$, dan Moses Glorino Rumambo Pandin ${ }^{3}$

\author{
1Azizah.pauleta.arthamevia-2020@fib.unair.ac.id \\ ${ }^{2}$ rachel.arifa-2020@fib.unair.ac.id \\ Corresponding Author: moses.glorino@fib.ac.id \\ Faculty of Humanities, Airlangga University \\ Jalan Dharmawangsa Dalam Surabaya, Jawa Timur 60286
}

\begin{abstract}
This research is motivated by mass communication and retrieval of information on Instagram, creating hate speech on digital platforms. With the availability of social media as a way of conveying the essential knowledge, society's pattern has evolved, either implicitly or unseen, causing bias in culture, ethics, and norms, resulting in conflict. Within the axiological analysis, this study intends to identify hate speech on Instagram and analyze the effectiveness of digital ethics. The study's subject is an improper Instagram comment. This research method uses a literature review method. This research collects data from various journals and finds proof of hate speech on Instagram. The freedom of expression results in this literature study state that many social media users do not apply excellent and polite social media ethics. Besides that, axiological studies supported these results that do not help ethical skills related to moral and aesthetic values. In addition, many Indonesian netizens still spread hatred intentionally or unintentionally on social media. Therefore, there is a need for education and proactive action for Indonesian netizens to use social media.
\end{abstract}

Keywords

axiology, digital ethics, hate speech, Instagram

\section{INTRODUCTION}

Science's philosophy has ontology, epistemology, and axiology. Ontology is the essence of what humans want to know. Humans want to understand the existence of "existence" or expansion that the five senses can absorb in this case. Epistemology is the foundation that reveals how humans obtain truth or knowledge. Epistemological knowledge directed to the concept of axiology. The concept examines the use-value of expertise. Besides that, axiology is divided into two categories: ethics and aesthetics. Ethics can be interpreted as principles that justify us in their application (Karimah and Wahyudin, 2010). On the other hand, KBBI (Kamus Besar Bahasa Indonesia) shows that branches of philosophy discuss art, beauty, and human responses. A crucial issue in this era is digital ethics on social media regarding axiology studies.

Digital ethics comes from sincere intentions and then expressed through calm, patience, and empathy in communicating. The etiquette of speaking on the internet is known as netiquette. Netiquette is the rules and procedures for using the intern to express or exchange information between groups of people in a mediated system. Netiquette encourages users to obey ethical and moral laws (Afriani and Azmi, 2020). Besides that, social media is a digital space for dialogue and interaction to create communicative ideas. The internet and social media have impacted many aspects of human life; language is no exception. Social media is not just a tool to help users facilitate all forms of communication activities but has become a need to be met. There are many conveniences and advantages of using social media. In addition, social media can make users connected in all parts of the world.

Currently, the most popular platform to communicate virtually is Instagram. Instagram is a platform that has a practical communication function and has become a suitable communication medium and becomes a communication medium through photo signification. Instagram is a site used to display text and photos, which over time are used as messengers by users. Instagram users in Indonesia are $86.6 \%$ of the total population. However, the existence of Instagram also has a bad influence on its users such as low ethics and morals, especially hostility speech. Hate Speech 
is an occur of connection carried out by a person or group in the state of inducement, incitement, or insult to another individual or group in terms of sundry aspects such as ethnicity, gender, disability, sexual exposure, belief, etc.

There are several aspects behind this research question. Firstly, our target is Indonesian netizens who use Instagram. Secondly, this research's intervention shows how cruel the behavior of netizens in hate speech on Instagram is. Thirdly, this research used various journals about hate speech comparison. Fourthly, after conducting some research. Therefore, this research already has the same factor and effect. Lastly, the context of this research is focused on some journals that explained bad comments appearing on Instagram. Hence, the research question is vital because they determine the next step in the literature review. These research aims are to identify hate speech on Instagram and elaborate on the effectiveness of digital ethics using an axiological perspective. Hopefully, this research can be a reference and educate Indonesia netizens to implement digital ethics in social media.

\section{METHOD}

This research uses a literature review method with data collection techniques then examines sources such as books, scientific journals, library records, and previous research (Septiadi, Kusnanto, and Supangat, 2019). Moreover, the references in this study mostly come from scientific journals related to the issues discussed, which are from the Google Scholar database and the Unair repository. The keywords we used in this search were "philosophy" and "axiology" and "digital" and "ethics" and "social media". From those results, we included 30 articles related to our discussion. Hence, the results of this study become a research journal that examines the ethics of netizens on social media Instagram. With various data, the authors organize the data neatly, systematically, and as completely as possible (Poerwandari, 2011).

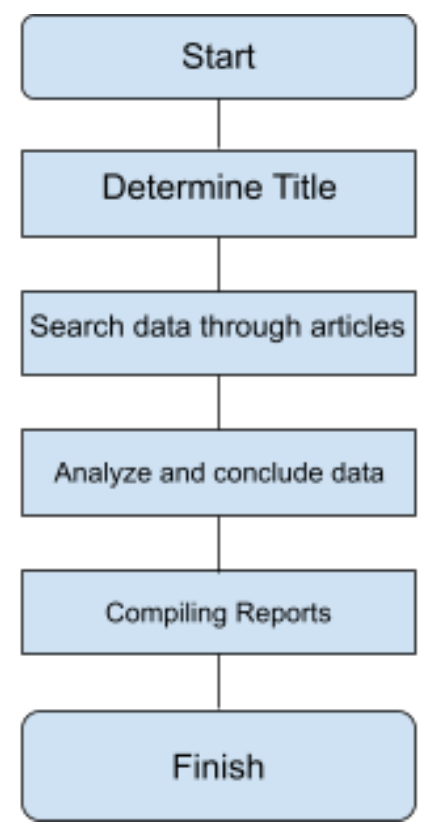

\section{RESULT}

To observe behavioral patterns and further analyze how effective the digital ethics of Indonesian netizens are. The Digital Civility Index (DCI) 2020 survey by Microsoft of 50,000 people in 32 countries states that Indonesia is ranked 29th as a social media user with the lowest level of politeness in the Asia Pacific. And provide appropriate solutions to minimize bad digital ethics such as hate speech on social media. 
The consequence of this literature study is that many social media customers still do not obey the noble and polite social media ethics. Hate speech issues are commonly found on Instagram. These include bullying, sarcasm sentences, and arguments in the comments column between supporters. Those problems are motivated by various factors and reasons. On the other hand, it also triggers impacts for the parties concerned. As a result, axiological studies support this result which does not help moral abilities associated with ethical and aesthetic values.

\section{DISCUSSION}

\section{The Factor of Hate Speech}

Hate Speech is an occur of connection carried out by a person or group in the state of inducement, incitement, or insult to another individual or group in terms of sundry aspects include SARA, sex, belief, and others. Some factors affect the occurrence of hate speech, including:

a. Factors within the individual include a practical psychological element that encourages the individual to do something, namely motivation. Hate speech makes individuals want to do that, which starts with envy. As in self-satisfaction, who thinks other people are happier, have everything, or are better than life.

b. The factor of public ignorance about hate speech includes insulting behaviors received by individuals or groups based on norms and fairness on social media. Also, lack of information for the public to be more attentive or aware of crimes or hate speech towards others. It can be seen in everyday depictions on several social media pages that still normalize those who get better those who have 'beautiful' or 'ugly' photos with body shaming which is often done in comments on viral social media.

c. The factor of facilities is indirectly the impact of social media, which is now necessary for every individual to get information. For example, on Instagram in 2021, several foreign artists were desperate to commit suicide because of malicious comments they received from social media. In addition, it is not uncommon for some artists or influencers who decide to quit the entertainment world because they are not strong in the hate speech they receive from social media.

d. The factor of lack of social control. Both from internal, namely the family, and externally including the surrounding community. The loss of control causes the blurring of existing social norms, causing conflict. Social control that we often forget is the attitude of indifference to others who think that starting from what we type with our hands, we become uncontrollable and arbitrarily under the pretext problem.

e. The community interest factor, maybe this cannot be related to individuals in globalization. There is also a lot of false information that can increase hate speech behavior. For example, Fan War or war between KPop fans is aggressive behavior that is aggressively commented on by fanaticism on idols. Fan war occurs because many fake accounts provoke a problem.

Based on these factors, a person can do hate speech indirectly. The forms of scorn are euphemism or softening of meaning, dysphemism or expressions with offensive connotations, labeling or use of offensive words, and stereotypes or use of the negative statement. Through a review of various journals, most of the Indonesian netizens made comments of sarcasm and bullying.

\section{Sarcasm Sentence}

Many people use social media to carry out the communication process, especially in the current digital era. Sarcasm is a style of language that contains insults, and reproaches that are less pleasant and hold bitterness that demeans social status. The use of sarcasm sentences themselves to show their existence, netizens want to use the opportunity to hitch a ride with fame, express expressions, express emotions, dislike Instagram users, and so on. The 
increasing use of the internet in Indonesia has triggered many netizens to use sarcastic sentences in their daily lives on social media.

Most Indonesian netizens use satire sentences roughly and directly target Instagram social media users. The use of sarcasm sentences consists of harsh, harsh sarcasm, and obscene. Hence, the level of use of Indonesian netizens' sarcasm language is very diverse. Slightly extreme sarcasm is a statement used to convey anger, annoyance, and dissatisfaction, the style of rude sarcasm is directly uttered to someone using bad words. Examples of sarcasm sentences taken from the Instagram comments column:

1. reziiamalia_said "itu badan apa karung beras sahabat?"

2. Wahyuhartamonoo said "KEKEYI TOLONG MUNDUR DIKIT, CONGORNYA KEMAJUAN"

3. Nadiaahmad18 said "Gembroot editan. muliho tandur neng sawah"

4. Arumnilawaty said "badan sama muka sama2 lebar boorrrr"

5. Choviie said "Dih sok cantik lu.. Gag usah berulah deh jenglot... Pakek nyentil2 kak @ dewiperssikreal hahhaha anjir kelaperan situ karna udah gg laku.. Miris yah"

Sentences of sarcasm number 1 to 5 contain elements of physical bullying. Sentence number 1 equates the person he resents with a sack of rice, sentence number 2 intends insult physically because the person being insulted has barren teeth, sentence 3 means to insult a fat body and is photographed always being edited out of frustration. rice fields, sentence 4 equates people's faces with regrets as wide as their bodies, sentence number 5 states that they don't pretend to be beautiful and equate people with "jenglot" and taking names because they are no longer sold as artists.

To summarize, the use of sarcasm sentences is nothing but to show their existence. Netizens want to use the opportunity to ride fame, express expression, and dislike Instagram users. Internet use in Indonesia is increasingly triggering many netizens to use sarcastic sentences in their daily lives on social media. The impact of sarcasm sentences is different for each individual. However, it does not close the negative effect of sarcastic statements on psychology, such as bullying.

\section{Cyberbullying}

With the existence of social media, many people use social media as lace to freely express their opinions. Social media is a medium for communicating and used for discussion. Although this is certainly a new problem, many people are reckless in saying their media because of the freedom of expression. One of the impacts of this freedom of expression is cyberbullying, hate speech, and also sarcasm.

Cyberbullying is one of the types of infractions that purposefully damage others, such as using harsh language in comments, body shaming, and bullying. Experts are focusing on cyberbullying since it is so common among teenagers. On social media platforms like Facebook, Instagram, and Twitter, sentences are written with varied motives in mind, such as being sarcastic, offensive, or even threatening. Users of social media accounts may or may not be aware that the sentences they put on social media can have unintended consequences or elicit unwelcome remarks, which is a type of bullying.

As stated by an inquiry guided by the Indonesian Internet Service Providers Association (APJII) in May 2019, cyberbullying is becoming more prevalent in Indonesia. According to the survey result, $49 \%$ of internet users have been victims of cyberbullying on social media. However, 31.6 percent of victims simply stood by while these actions were carried out, while only 5.2 percent of victims retaliated, and only 3.6 percent of victims reported these actions to authorities (Jayani, 2019).

Direct cyberbullying and indirect cyberbullying are the two varieties of cyberbullying. Immediately cyberbullying happens immediately when the perpetrator targets the toll immediately through the toll's domain. In 
contrast, indirect cyberbullying occurs when the perpetrator targets the victim indirectly through public fields such as social media, the internet, and others. The following are types of cyberbullying:

1. Flaming (burning) sends a text message containing words full of anger and frontal.

2. Harassment (nuisance) is messages that contain disturbances in email, sms, or text messages on social networks, are carried out continuously.

3. Cyberstalking is disturbing and defaming someone intensely to create great fear in that individual.

4. Denigration (defamation) is the process of slandering someone on the internet to damage the person's reputation and good name.

5. Impersonation (imitation) is dissembling to be somebody else and dispatching notifications or status that is not acceptable.

6. Outing \& Trickery is Outing is spreading other people's secrets, or private photos, whereas trickery is persuading someone with guile to get that person's private or personal images.

7. Exclusion: intentionally and cruelly removing someone from an online group.

When it comes to axiology, many problems arise from ethical procedures on social media, including:

1. shows that Indonesian netizens do not yet have good moral and ethical values by commenting at will without thinking about the feelings of others.

2. The applicable law regarding the ITE Law in Indonesia is still not adequate.

3. Social media users on Instagram tend to override moral and ethical values in public forums.

An effort to overcome these problems is to better educate and limit words in the Instagram comments column. So cyberbullying can be quickly resolved because the phenomenon of cyberbullying on social media is not a trivial thing but something that has a massive impact on the victim. Usually, the victim will feel insecure, experiences stress and depression until suicide. In addition, with social media, communication between humans is not limited. Therefore, the presence effect is hoped that users will be able to control themselves, be ethical, and politely follow axiological values so that social media can produce positive results.

\section{Point of Axiological View}

From an etymology standpoint, axiology comes from two Greek syllables. The Greek syllable "Axios”, which indicates "worthy" whether "suitable," and logos, which implied "knowledge" whether "learning". Furthermore, value is derived from the Latin Valere, which means helpful, capable, empowered, valid, or strong, and refers to the attribute of something that makes it appealing, useful, or interesting. Whether we like it or not, science will be accompanied by the development philosophy because the balance between science and philosophy will be a means of controlling scientific axiology (values), ushering in an equally valuable human civilization. According to the phrase, axiology is a study linked to the philosophy of value that can produce advantages. Value is a phenomenon, yet it does not exist in space or time. Furthermore, value is a logical essence that may be comprehended by logic. Meanwhile, in philosophical discourse, axiology refers to ethical (moral) and aesthetic (beauty) difficulties (Zaprulkhan, 2016).

\section{CONCLUSION}

Hate Speech is an occurrence of connection carried out by a person or group in the state of inducement, incitement, or insult to another individual or bunch in terms of sundry aspects including SARA, gender, belief, and others. With the existence of social media in this digital era, communication between humans is not limited. It also stated that with social media, it is hoped that users will be able to control themselves and be ethically and politely following axiological values so that social media can produce positive results. Based on that statement, the manners of 
Indonesian society in social media are still terrible. In response to this, Instagram finally found a solution to reduce this cyberbullying phenomenon by limiting content in the comments column and setting policies so that we can respect each other more. It's up to us as users who should be more sensitive and self-controlled and better able to sort out which things deserve to be published and shouldn't be posted on social media to reduce the cyberbullying phenomenon that often occurs on the Instagram social media platforms.

\section{FUND INFORMATION}

The writers affirmed that no commissions were entangled in sponsoring this work.

\section{CONFESSION}

Our philosophy of science professor has escorted this research. His name is Mr. Moses Moses Glorino Rumambo Pandin. He contributed to providing the themes contained in this paper. He has also prepared this paper, including writing systematics and publisher advice. His advice helped us so that we could finish this paper.

\section{REFERENCES}

Agnensia, N. P. (2019). Fan War Fans K-Pop dan Keterlibatan Penggemar Dalam Media Sosial Instagram.

Anim, Armanto, D., \& Sari, N. (2021). Perspektif Kajian Aksiologi Pada Pembelajaran Daring di Era Pandemic.

Budijanto, R. (2019). Pertanggungjawaban Pidana Media Massa Siber di Era Kebebasan Informasi.

Cahyati, A. S. (2020). Analisis Penggunaan Kalimat Sarkasme Oleh Netizen Di Media Sosial Instagram.

Dasuki, M. R. (2020). Tiga Aspek Utama Dalam Kajian Filsafat Ilmu; Ontologi, Epistemologi, dan Aksiologi.

Dwy, N. S. (2019). Literasi Informasi Digital Di Kalangan Mahasiswa Dalam Memanfaatkan Media Sosial (Jejaring Sosial).

Eka, R., \& Pandin, M. (2021). Analizing the Importance of Character Education for Millennial Generations in the Digital Era.

Farida, N. (2019). Kemampuan Literasi Kritis Pada Net Generation Pengguna Instagram. 
Firmina, A., \& Partini, P. (2019). The Hate Speech Behavior of Teenagers on Social Media Instagram.

Hidayat, D. B., Surono, A., \& Hidayati, N. M. (2021). Ujaran Kebencian Pada Media Sosial Pada Saat Pandemi Covid-19 Studi Kasus Putusan No.72/Pid.Sus/2020/Pt.Dps.

Hidayat, M. A. (2020). Motif Ujaran Kebencian Di Media Sosial (Studi Kasus Pada Mahasiswa Ilmu Komunikasi Universitas Islam Kalimantan).

Jayani, D. H. (2019). Survei APJII: 49\% Pengguna Internet Pernah Dirisak Di Medsos.

Kusumaningati, R. M. (2019). Kosakata yang digunakan sebagai offensive language terhadap Cardi B pada akun instagram@worldstar.

Madani, B. F. (2020). Hubungan Antara Perfeksionisme Dengan Kecenderungan Kecemasan Sosial Pada Remaja Akhir Pengguna Instagram.

Mawarti, S. (2018). Fenomena Hate Speech Dampak Ujaran Kebencian. Toleransi: Media Ilmiah Komunikasi Umat Beragama.

Mutiah, A. T., Albar, I., Fitriyanto, A. R., \& Rafiq, A. (2019). Etika Komunikasi dalam Menggunakan Media Sosial.

Nurhadiyanto, L., \& Octaviani, M. (2021). Analysis Of Neutralization Theory in Hate Speech Cases Against Kekeyi, Young Lex And Nissa Sabyan on Instagram.

Nurjanah, D., \& Putra, G. M. (2020). Hate Speech Detection In Indonesian Language Instagram.

Pertiwi, A. W. E. (2020). Analisis Ujaran Kebencian Dalam Akun Instagram Lambe Turah.

Putra, G. M. (2020). “Hate Speech Detection in Indonesian Language Instagram,” 2020 International Conference on Advanced Computer Science and Information Systems (ICACSIS),. 
Putri, L. R., Sudarsono, S. C., \& Wardani, M. M. S. (2021). Kekerasan Verbal Dalam Kolom Komentar Di Akun Instagram Garudarevolution Pada Bulan September 2019.

Risnawati, E., Nasrul, \& Sugiyo. (2019). Penggunaan Bahasa Dalam Berkomentar Bermuatan Kebencian dan Hinaan di Media Sosial Instagram dan Twitter.

Rochman, A. N. (2021). Perilaku netizen dalam beretika di sosial media. Perilaku Netizen Dalam Beretika Di Sosial Media.

Sa'idah, F. L., Santi, D. E., \& Suryanto, S. (2021). Faktor Produksi Ujaran Kebencian Melalui Media Sosial.

Savira, A. (2020). Praktik Mom Shaming Oleh Netizen Indonesia Terhadap Selebriti Yang Melakukan Sharenting Di Media Sosial Analisis Tekstual Pada Akun Instagram@AndienaisyahDan@Rachelvennya.

Suga, T. A. (2020). Hubungan Antara Fear of Missing out (Fomo) Dengan Intensitas Penggunaan Media Sosial Pada Mahasiswa Psikologi Universitas Negeri Surabaya (Unesa).

Suryani, Y., Istaningrum, R., \& Hanik, U. S. (2021). Linguistik Forensik Ujaran Kebencian Terhadap Artis Aurel Hermansyah Di Media Sosial Instagram.

Umroh, F. (2019). Ujaran Kebencian (Hate Speech) Pada Jejaring Media Sosial.

Wirmando, W., Anita, F., Hurat, V. S., \& Korompis, V. V. N. (2021). Dampak Penggunaan Media Sosial Terhadap Perilaku Bullying Pada Remaja.

Yohanna, A. (2020). The Influence of Social Media on Social Interactions among Students. 